\title{
'Slow Poison' or Child Empowerment? A Review of Enid Blyton and the Mystery of Children's Literature
}

\author{
Robin Pope
}

60 ut what hope has a band of desperate men against four children?' Eileen Colwell's question, posed in 1948 in reference to Enid Blyton's Famous Five adventure series, is apparently still valid today. The 1997 centenary of Enid Blyton's birth created quite a few ripples in Britain, with repackaging and marketing of her most enduring books, special stamp issues, a conference devoted to her at the Roehampton Institute, an Oxford Union debate concerning her 'ideological soundness', and a $£ 6.2$ million film of the Adventure series made by Cloud 9 ; there was even a fourand-a-half hour TV special in Germany. If, like me, you spent a large part of your childhood consuming Blyton's output, you will find David Rudd's study, Enid Blyton and the Mystery of Children's Literature (Macmillan, 2000) a fascinating read, for even without any nostalgic element she is an absorbing cultural subject.

Rudd's book investigates what he terms 'the Blyton phenomenon', whose extent will surprise many Australian readers who, while aware that various Blyton books are still in print, will be astonished to find that even before the latest TV series in 1997, the Famous Five books were still selling at a million copies a year. In his third chapter, Rudd traces the career of this controversial author whose very name has provoked many hot debates between those with interests in literature, in children, and in culture.

Blyton began her career as an educator in the 1920s, influenced by the work of Froebel, but she also had her first book published in 1922. Although she eventually abandoned teaching for full-time writing she successfully established herself in the field of education and wrote extensively for various manuals on teaching until the mid 1930s. Rudd's study is thorough in its consideration of the secondary texts pertaining to his subject, and his review of her life includes acknowledgement of Barbara Stoney's biography (1974; rev. ed. 1992), which uncovered much about Blyton which was previously unknown. even to her daughters. He contrasts this with Blyton's own autobiography The Story of My Life, in which Blyton's life seems, by her constructionof events, to have hardly begun until she became a writer. He further demonstrates how she mythologizes her life for her readers, fantasising about her family and emphasising the importance of mothers: '.. we are a happy little family.
I could not possibly write a single good book for children if I were not happy with my family, or if I didn't put them first and foremost' (quoted pp.28-9 from Smallwood, 1989, p. 12) He juxtaposes this with a fragment from her younger daughter's autobiography, '.... as one of her two children who should have been the closest to her of all, I saw her only as a distant authority, a clever person, a strong and imaginative actress on the little stage of my life but never, or almost never, a mother' (ibid.). Blyton 'ignored her own mother for almost 30 years, not even attending her funeral', he pointedly adds. His claim that Blyton's audience constituted her most significant Other, 'mirroring back to her, in exactly the Lacanian sense, her existence and worth' (p.190), seems a credible conclusion on the basis of his evidence.

Rudd establishes how Blyton created a public persona which was at variance with the private person, and how she became one of the first to create a brand loyalty by attaching her famous signature to the cover of many of her works, further extended by producing spin-offs from Noddy through merchandise, theatre, film and TV rights (consolidated in the establishment of Darrell Waters Ltd in 1950). By the mid-1950s, 'Blyton was something of a Disney enterprise herself', Rudd comments. At her peak in the $1950 \mathrm{~s}$ she was producing fifty titles a year, at a rate of about 10,000 words a day, and the Noddy books, which began in 1949, had sold over 20 million copies by 1960; and 52 companies were selling non-book Noddy products. Thus, by the time of her death in 1968 Blyton was indeed an industry. With astute marketing, that industry has continued unabated since her death, with rewrites, sequels and film and stage versions of her various series being produced by a stream of writers who have included her elder daughter. In the 1990s, after an earlier unsuccessful foray, a rebadged Noddy finally broke into the US market, where he is available on TV and CD-ROM. Rudd claims he is more popular now than Sesame Street. A final curious fact noted by Rudd is that in 1998 Enid Blyton Ltd earned a Queen's Award for Export Achievement. There is little doubt that Enid Blyton has been and is a marketing phenomenon, and can lay serious claims to being a cultural reference point. In the political arena various parallels between Blyton and Margaret Thatcher or John Major have been made and a 
range of spoofs and parodies in cartoons and comic strips, titles of music bands and songs and Internet groups further demonstrate her iconic status.

In chapter four, Rudd offers an attractive proposal in his re-assessment of Blyton as a storyteller from the oral tradition, rather than as a 'literary' writer. He quotes Blyton's stated preference for being known as a storyteller, then cites his reasons for his hypothesis. In her work he identifies many of the qualities often associated with oral storytelling, such as her use of stock characters who perform required actions in her narratives; her use of repetition; the centrality of action (rather than character) to her adventures; her parataxic sentences; her intrusion as narrator to establish a sense of immediacy with her audience. Additionally, he notes how she frequently reworked the same material, making only slight variations, just as a storyteller might improvise on a basic plot structure. However, his list of so-called 'literary qualities' in contrast to oral traditions, drawing on notions of literariness current in the Leavis tradition, seems a peculiar inclusion made, presumably, on the basis that such notions of aesthetic quality had currency in the time Blyton was producing her work. This is the source of my greatest disappointment in his study: it makes insufficient use of modern literary theories, many of which (especially postcolonialism, and post-structuralism) would have provided greater insight into Blyton's work.

I found Rudd's response to the many critics of Blyton unsatisfying, relying as it often does on statistical evidence, in place of examining actual representations in her texts. His second chapter, titled 'Theory and Method', promises a 'discourse approach' based on textual analysis, cultural and historical contextualisation, and reader responses. That this promise remains unfulfilled is most evident in the discussion of racism, when neither a discourse approach nor specific textual analysis occur. The closest to a definition of racism is the claim that 'It is when [a] term is used against a people already seen as a socially distinctive group - usually because they are socially disadvantaged in some way - that [a] term becomes abusive' (p.140). While his claim that the golliwog as signifier is unstable is valid, it would have been more convincing to examine actual passages for evidence of racist discourses, which have a much wider field of operation than in the overtly oppositional as his definition implies, and as Edward Said cogently demonstrated in Orientalism.

Rudd has been scrupulous in surveying the existing literature on his subject, although he is limited by his means of assessing it. He identifies three previous approaches, but he categorises these in terms of a bygone era: 'literary' (Leavisite) assessments; those based on Piagetian ideas about child development; and reader response. This seems to wilfully ignore recent critical assessment of Blyton which draws on later literary theories - I was impelled to reread Vicki Coppell's 'Ideology and the Class Bully: Enid Blyton's Malory Towers', for instance, which we published in this journal in 1996, to remind myself that Blyton has been the focus of studies using recent critical ideas. Rudd seems to be under the misapprehension that recent literary theories such as marxism, postcolonialism etc demand texts which are utopian:

\section{Well-intentioned attempts to write texts that install p.c. (sic) values often founder because they lose this tension between reality and fantasy, trying to make the reality utopian (no sex discrimination, no inter-group tension, no violence and so on); whereas the more successful, but often more criticized texts not only recognize the need for contraries, but are themselves written by people with a personal investment in such issues, giving their tales a deeper edge. \\ (p.203)}

This claim serious misrepresents current knowledge of the ways in which texts work. Of course no one would read about a world which has attained perfection: there would be no purpose ('no sex discrimination, no inter. group tension, no violence and so on') to the narrative, which requires a plot, a 'problem', a purpose for the telling. One of the gifts brought to us by recent critical theories has been an awareness of narrative as a construction, created by its author who chooses what kind of a world will be represented. It does not have to be a utopian world, as Rudd seems to think - that would indeed be a fantasy. But it should try to provide a range of representations, so that contrasts and balances are found, as in the 'real' world. A utopian world (unless it is parodic) would be as unbalanced as a constructed 
world in which all mothers were negligent, all villains were identifiable by the family dog and all schoolteachers were unfeeling. Curiously, Rudd recognises this when the writes about gender representation in the Famous Five series, noting how George and Anne balance each other as different models of female childhood, and he is at pains to note how Blyton presents Jo and Henry as other transgressive females in the series (p.116). However, his analysis of representations is frequently reductive, as illustrated by his response to critics who claim Blyton often creates working-class, or foreign villains. His quick summary of the Famous Five series shows that there are tenmiddle-class villains, as opposed to eight working-class and four foreign. However, this elides the balance and nature of representations in the individual books of the series, each of which makes its impact on readers. Blyton's villains could have been a fruitful source for his promised but unrealised textual analysis (p.4), providing material for deconstruction and interpretation rather than simple number-crunching.

Even where some analysis takes place, as in his discussion of class in the Famous Five and Malory Towers series in chapters six and seven, there seems to be an unwillingness to accept the possible effects of naturalised values in texts. He concludes chapter 6 (on the Famous Five) with this statement,

In this chapter, I have re-examined the Five books in terms of some of the main social criticisms made of them: that they are anglocentric and classist. I have sought to argue that they are not so in any simplistic way...

(p. 108)

I think Rudd is implying by this statement that since Blyton was writing the books both during World War 2 and the Cold War years which followed, when ethnocentrism was rampant, and the social class hierachies were far more evident than they might be today (one of his book's strengths is its historical contextualisation), then these representations are 'justified'. If I am correct in my reading, then this seems to be an apologia for asserting that a book may only be read in terms of contemporaneous ideas and events - a view which would preclude any modern readings of past texts; it also ignores the fact that change only occurs because there are always people who are able to step outside the boundaries of convention, and who are leaders in new practices and attitudes which bring about change. His claim is linked to an earlier statement in the same chapter:

Whereas adults might find some of the above discourses on gender, nationhood and class suitably serious, theyoung reader would probably code them as 'boring'.

(p. 102)

Such a statement assumes that readers are fully conscious of the values and discourses which a text naturalises by apparently representing the world 'as it is'. While the closure of a narrative might reveal the intended values of the implied author, it is the (often) unintended embedded values which have power to influence the 'ideal reader' because they simply reinforce existing attitudes. As Vicki Coppell shows in the article cited above, the Malory Towers stories consistently endorse various forms of bullying in order to coerce readers to accept the middle class values which are held by the 'good' female protagonists of the stories. Readers are not likely to find these discourses 'boring', for they are more likely not to notice them at all, when they confirm already-held views about how the world should operate.

Although we know that readers are notoriously varied in their perceptions of a text, Rudd does provide some encouraging data which indicates that some young readers can be resistant to the world it constructs. He provides a range of responses from today's readers which indicate how some young readers are not taken in by the values the text offers. In addition, he also uses responses from readers past and present to demonstrate how Blyton's texts have been, and continue to be, 'psychologically satisfying', because children are empowered. Her work, he claims, 'protects and strengthens young egos', by creating a fantasy world in which the child proves superior to the adult (p.189). He concludes his study by observing that 'Blyton's works thus celebrate being rather than becoming'. While I have reservations about the nature of Rudd's journey in reaching this point, I find myself agreeing with his conclusion.

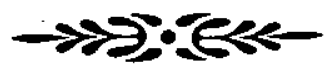




\section{REFERENCES}

Smallwood, Imogen (1989) A Childhood at Green Hedges [a fragment of autobiography by Enid Blyton's daughter]. London, Methuen.

\section{$\rightarrow$ P:EK}

\section{NOTE}

1. Quoted by Rudd (p.33), from Sheila Ray (1982) The Blyton Phenomenon: the Controversy surrounding the World's Most Successful Children's Author. London, André Deutsch, p.52.

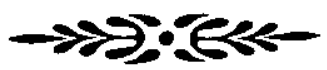

